\title{
Virtual-cultural Tourism of Sesekaran Topeng in Kampung Budaya Polowijen: New Look and Challenges of Traditional e-Tourism Packaging in the Covid-19 Pandemic
}

\author{
Siti Zurinani ${ }^{1}$, Muh. Fatoni Rohman ${ }^{2}$, Fatmawati $^{3}$ \\ \{zurienanis@ub.ac.id ${ }^{1}$, muh_fatoni@ub.ac.id ${ }^{2}$, fatmawatiu@ub.ac.id ${ }^{3}$ \} \\ Universitas Brawijaya, Indonesia ${ }^{1,2,3}$
}

\begin{abstract}
This paper discusses the research results of the relationship between tourism and the pandemic. Its primary focus is analyzing the Polowijen Cultural Village's creative work (Indonesian: Kampung Budaya Polowijen or KBP) community in developing local tourism. KBP has been a thematic tourism icon of Malang since 2016, changing the Covid-19 pandemic. This pandemic has apparently bred changes in tourism. The correlation between tourism and pandemic is obviously seen in two flanks of tourism characteristics, i.e., vulnerability to and resilience against disasters or pandemics. The community resiliency in retaining tourism is indicated by how they creatively design e-tourism in a form of 'sesekaran topeng' virtual cultural tourism. The pandemic does not hinder the community's optimism about tourism. For instance, the discovery of traditions, the repositioning of the Ragil Kuning Mask, the packaging of the 'sesekaran topeng' tradition in Kampung Budaya Polowijen (KBP) in Malang City East Java indicate community engagement in the social development of tourism and resilience against the Covid-19 pandemic.
\end{abstract}

Keywords: Virtual Cultural Tourism, Sesekaran, Topeng, e-Tourism

\section{Introduction}

The beginning of 2020 was when global exposure to the Covid-19 pandemic started. Sugihamretha [1] defined Covid-19 as a global epidemic harming human and social dimensions. After spreading from China, this pandemic spread rapidly to 210 countries, including Indonesia. A series of health protocols and restrictions on mobility access has been carried out to minimize the negative impact on the human and social dimensions. It includes restrictions on mobility access related to tourism activities. The pandemic has affected tourism significantly.

This paper views tourism as a sector directly affected by this global disaster. Global tourism is at the threshold of vulnerability, and it triggers the economic downturn and other aspects of life. The researcher attempts to observe tourism as a vulnerable sector but resilient to disasters or crises simultaneously. When dealing with the Covid-19 pandemic as a global disaster, the researcher considers cultural sustainability and creative steps for tourism development in the Kampung Budaya Polowijen or KBP (Polowijen Cultural Village), in Malang City, East Java.

Kampung Budaya Polowijen (henceforth: KBP) is a cultural tourism destination in Malang City and the main destination for domestic and foreign tourists for four years. KBP brought up 
the theme of Ken Dedes mythology and Topeng Malangan culture, typical of Malang City. The presentation of Malangan cultural traditions strengthens the cultural tourism narrative developed at KBP. It is implemented by developing tourism relations and community involvement. After developing into a thematic tourism village for four years, KBP has been quite popular. The popularity is supported by data collected (sub-district) for one year: approximately 7,000 domestic and foreign tourists have visited KBP. It is also a destination for cross-cultural comparative studies from the regions. The cultural tourism development model in KBP is a reference for development in other areas. In this context, KBP is an essential agent in cultural sustainability.

The changes in 2020 due to the Covid-19 pandemic required KBP to develop a creative strategy for providing tourism entertainment. Thus, two problem formulations are presented in this paper: (1) the form of cultural tourism presented at the KBP, and (2) the extent of creative efforts in developing KBP tourism during the Covid-19 pandemic. Pandemic affects tourism demands, and Covid-19 has been considered the most challenging time. Several studies in the last five years included the SARS pandemic and its effects on tourism [2][3][4]. These studies are still relevant for mapping tourism disaster mitigation during the current Covid-19 pandemic. Using the general equilibrium model (GTAP), Gopalakrishnan [5] stated that implications of the Covid-19 crisis on the tourism sector could be carried with comprehensive recovery efforts based on government recommendations.

In addition to socio-economic recovery efforts based on government recommendations, creativity rising from the downturn due to the Covid-19 pandemic has emerged in society. Gradually, KBP tourism combines e-tourism with its activities. Although tourism is susceptible to disasters, it is also resilient. Referring to Reivich and Shatte [6], resilience is the ability to cope and adapt when facing serious events or problems in life, including the capacity and ability to respond in crisis/emergencies. Through this framework, this paper intends to answer the problems formulated by using ethnography and nethnography methods.

\section{Research Methods}

As a result of research on the Polowijen Cultural Village (also called KBP) in Malang, this paper employed the ethnographic method to collect and analyze data. The researchers directly collected the data through a digital-ethnography tool, adapting ethnographic research methods to study and interpret digitally-mediated cultures. It included social media ethnography [7] and digital auto-ethnography [8] due to meeting-restrictions during the pandemic. The digital media involved were the KBP website, online mass media, and social media. Moreover, the research informants were development actors, local people (activists of the Polowijen Cultural Village), and people outside the Polowijen Cultural Village.

\section{Results and Discussion}

\subsection{KBP Development Context}

Based on Malang city's Central Bureau of Statistics (in Indonesia, BPS or Badan Pusat Statistik), 6025 foreign tourists and 2,423,076 domestic tourists visited the city in 2014. In 2018, the number increased: 124,267 foreign tourists and 3,795,229 domestic tourists. As the number 
of visitors grows, Malang City has improved the development and presentation of thematic tourism schemes, such as the Kampung Budaya Polowijen or KBP (Polowijen Cultural Village).

KBP is located at Jalan Cakalang RT 03 RW 02 (RT/RW is a typical Indonesian neighborhood association and part of the administrative division, which stands for Rukun Tetangga/Rukun Warga) in Polowijen Village of Blimbing District. The area extends about 2 $\mathrm{km}^{2}$. However, only a few parts of RT 03 RW 02 administer the cultural village; fifteen houses in this area (across the river and rice fields) were modified for the thematic scheme. The houses are accessorized with bamboo, masks, and wooden ornaments on their front walls. Above the river, the people built seven gazebos and a pavilion mostly made of wood and bamboo; these places are now the village center of various activities. Thematically, KBP puts forward the historical potential of Ken Dedes' mythology and the Malangan mask culture. The historical narrative claim is based on the archaeological findings of the Windu Ken Dedes well, Joko Lulo's remarks, and the discovery of the tomb of Ki Tjondro Suwono (also known as Mbah Reni), who was the mastermind of Malangan Mask. Based on KBP's historical records, Mbah Reni passed away in 1935 (year of birth unknown).

To develop its tourism, KBP reconstructed and accessorized 15 houses with bamboo ornaments in portraying a cultural house. Historically, one of the Malangan Masks was originated in Polowijen. The village has explored its potentials and revived Malangan Mask art as one of the cultural icons of Malang City by actively organizing Malangan mask dance and mask-crafting. It has also developed Malang batik using the Malangan mask and Ken Dedes motifs. As of today, it has developed traditional music and children's games (in Javanese, it is called dolanan), Javanese and Malangan poems/songs called macapat (a traditional poem/song), and a school with a cultural ambassador program (Indonesian: Sekolah Duta Budaya) come complete with a library.

Through grassroot development, such as thematic and tourist villages, the government attempts to boost community participation in development of KBP. The state takes initiatives to improve economic and social welfare; the community is invited to cooperate for the common good [9][10]. Such a model policy is known as the Bottom-Up policy: the community is given the authority to regulate various policies and desired development. They are deemed to be more capable and familiar with their environment than other parties so that they can design effective and environmentally-adaptive development strategies [11]. The policy can also increase community empowerment to join the development. It is expected that they will have a sense of responsibility for tourism development sustainability [10]. In this case, tourism prioritizing natural, social, community values, valuable experiences, and interactions for tourists and their organizers is categorized as alternative tourism [12].

KBP was inaugurated on April $2^{\text {nd }}, 2017$, and formally endorsed by the Mayor of Malang. The inauguration is a medium for the community to develop KBP tourism further. Aside from the government's support, the active role of local actors is crucial. Ki Demang is one of the locals exploring the potential and compiling the existing narrative in Polowijen, whose real name is Isa Wahyudi (Ki Demang is a name bestowed for his efforts in developing KBP). $\mathrm{He}$ holds regular meetings for Polowijen residents with experts in various fields related to KBP development, such as tourism, history, culture, and the creative economy. This effort expands KBP's access in development because of these relations. 


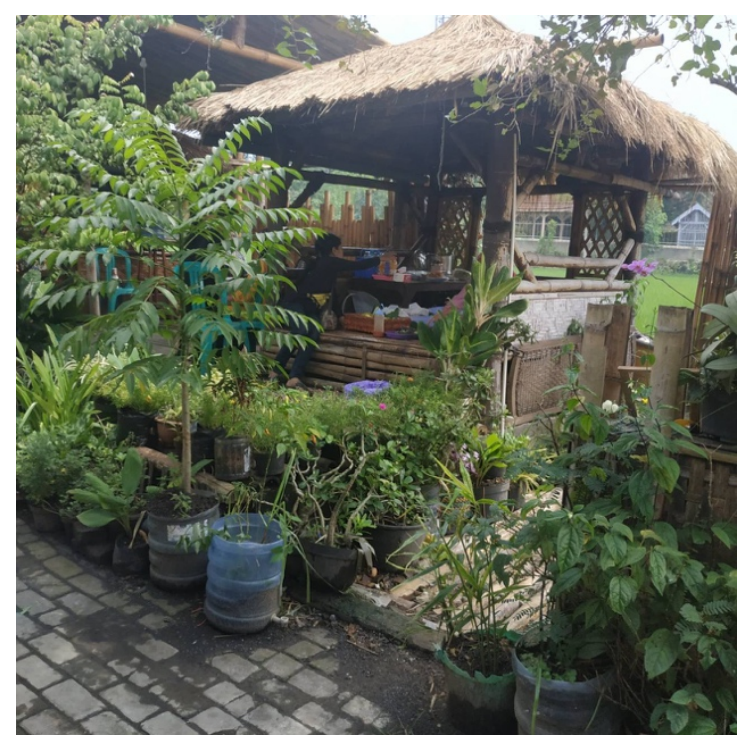

Fig. 1. One of the KBP gazebos used for activities (Personal documentation).

The government holds symposium on the history of Polowijen, Malangan masks, and workshops on batik and other crafts to strengthen KBP's sense of tourism. They prepared thematic substances and tourism attractions and made several infrastructure changes, such as renovating several houses to match the theme. It will take at least two years to improve the village infrastructure to mirror the desired design: unique, antique, beautiful, and attractive. Through various attractions, KBP can experiment with identity and political articulation [13]. Through activities and events, it can also open new social spaces and allow those that once were marginalized by dominant society to express various forms of cultural existence [13].

Currently, KBP has weekly, monthly, and yearly activities. The village's works of art are essential commodities in its commerce. During the KBP development, the Polowijen community gave diverse responses. In its initial development, the administrators held many training sessions to improve the community's abilities and skills, which were welcomed enthusiastically; many residents participated in the training activities. However, some refused subtly; according to an informant, the KBP and its administrators were underestimated because they unearthed Polowijen's history by showing various existing archaeological sites. The problem was that some residents of Polowijen believed that items from these sites are mystical and should have been left undisturbed. Nevertheless, this concern did not bother the KBP activists as they did not do any harm (mystical, taboo, heretic doings) to the items. They did it as a form of their love for culture and an effort to improve community welfare.

When viewed through the development model, KBP is classified as a bottom-up development, meaning that it is built through community initiative and participation in establishing the village as a tourism object and subject. It encourages creative economic growth to increase the surrounding community's welfare and acts as cultural preservation efforts for tourist attractions. Ideally, the development of alternative tourism, such as KBP, will develop better with government support.

The government must be the facilitator for the community, the main actor in tourism development [10]. The Malang city government stated that they support the thematic village 
development program because it can alleviate slum settlements. In this case, they contribute to preserving culture by inviting KBP to perform in various events. It brings a positive impact as it can also promote KBP. Additionally, the government makes thematic villages feasible as creative economy co-working spaces for Malang City by installing free wireless networks in each of the village centers.

\subsection{KBP Virtual Culture Tourism (e-Tourism) and Covid-19: Creative Efforts during the Pandemic}

Since implementing the health protocols to deal with the Covid-19 pandemic in early March 2020, the Indonesian tourism sector has been affected. After five months of inactivity, KBP started to reactivate its tourism activities, but on a limited scale, to prepare for the Grebeg Suro event in August 2020. The event involves a carnival and cleansing ceremony, sesekaran topeng (part of the ritual involving traditional dance), and a march to visit Mbah Reni's burial. Even during the Covid-19 pandemic, KBP holds the Sura ritual (a tradition held on the first day of the month of the Javanese calendar) online. It is driven by local actors and involves the local community.

Exploring the unique potential of Polowijen Mask from Malang City is laborious. To strengthen its tourism development, KBP has a yearly agenda. Tourism activities have been included in the KBP's calendar starting from the beginning of the year, including a ritual called Grebeg Suro; this tradition involves Sesekaran Uger and Malangan mask Penitisan (incarnation). It is a ritual respecting Mbah Reni as the original Polowijen Malangan mask creator.

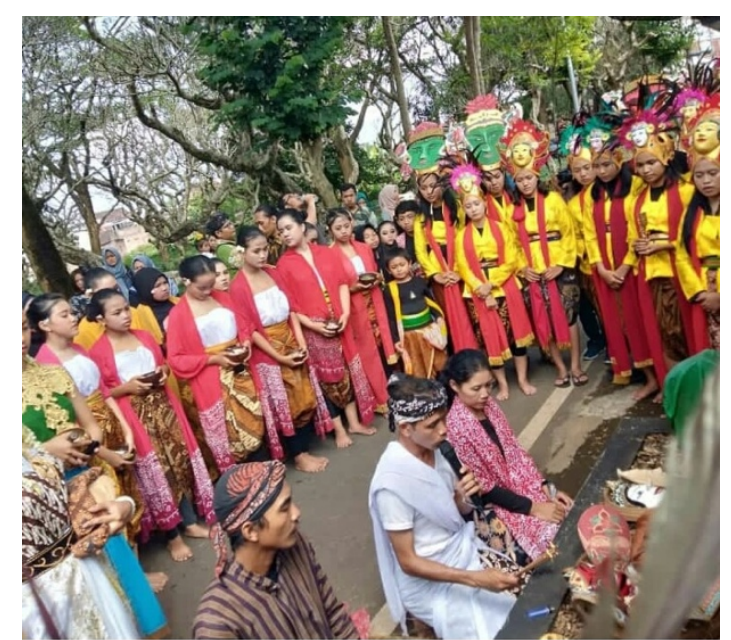

Fig. 2. Mask Purification Ritual (Before Pandemic) (Personal Documentation of Isa Wahyudi).

The Grebeg Suro procession began with an online broadcast via Zoom and YouTube, continued with sesekaran topeng on YouTube INSPIRE media TV [14]; as of March $21^{\text {st }} 2021$, it has been viewed 506 times. In the process, many dancers were involved and assisted by the local community. The tradition, usually presented onsite, was held differently; the number of dancers and participants in the procession was limited with the health protocol of Covid-19. The mask purification procession was led directly by Ki Demang. The Malangan mask dance was 
performed with the central figure Ragil Kuning, performed by Nyai Dardak Purwo. Nyai Dardak Purwo is the stage name of Agus Eko Suyanto, acting as a representation of Ragil Kuning (a typical KBP branding icon). Not only showing the Ragil Kuning play, but the event also featured the Ragil Kuning dance in the closing of the procession (after the ritual in Mbah Reni burial). Apparently, Ragil Kuning has occupied a special place in KBP; the Anoman Gandrung marked the start of the sesekaran to Mbah Reni's burial, and the Ragil Kuning dance closed the main event. This order of procession emphasizes that Ragil Kuning is a core icon valuable and meaningful for KBP.

Ragil Kuning is chosen as the Malangan mask icon at KBP to raise other figures besides Pandji Asmoro Bangun or Raden Inu Kertapati and Sekartaji Galuh Candra Kirana. Ragil Kuning, in Pandji's story, is the younger sister of Pandji Asmoro Bangun. Gunungsari, the husband of Ragil Kuning, is the brother of Sekartaji. Currently, Pandji is still a central figure, resulting in other figures being unpopular. KBP chose Ragil Kuning as an icon because she was considered to have values worthy of emulation. She is believed to represent a woman's purity, nobility, gentleness, and loyalty. Additionally, according to Ki Demang, the only mask with an ornament similar to Mbah Reni's was the Ragil Kuning's.

Ragil Kuning is the main commodity in attracting the wider community. The historical narrative and originality of the Ragil Kuning mask and its stories helped KBP shape its image. However, its historical narrative and originality do not function in a simple framework and do not work independently; they are affected by the actors involved in the village development. Robby Hidayat and Nyai Roro Dadak Purwo greatly influenced the process of making Ragil Kuning an icon of KBP. Robby Hidayat's role as the person who initiated the cultural village affected the making of historical narratives and shows. Robby Hidayat is a lecturer majoring in dance who is also an activist in Malang city's cultural activation; he teaches in Faculty of Letters, State University of Malang. He wanted the show to be as simple as possible. In an FGD (Focus Group Discussion), he said that the point was to make the show one of the developable attractions. He did not emphasize the sacred values in dancing; instead, he wanted something useful - utilizing existing human resources.

The principle of "simple development" is essential to be balanced with sacred values and spirituality obtained from a spiritual dancer called Nyai Roro Dadak Purwo. It is useful in reaffirming the historical value of Ragil Kuning without reducing the value of KBP attractions. Nyai Roro Dadak Purwo is known as a pawestri (meaning female in Sanskrit) dancer having a long spiritual journey. She inspired the dance to pray, worship, tell how grateful humans to the creator and show devotion to the ancestors. She has danced as Ragil Kuning three times; she has always visited Mbah Reni's burial as a form of service. Her actions depict the Ragil Kuning mask's sacred values and strengthen the foundation of KBP in narrating its distinctive characteristics.

The claim of the Malangan Mask culture and the discovery of the tradition or invented tradition is inseparable from the motivation of maintaining tradition with innovations. According to Hobsbawn [15], invented tradition is an act of re-emergence of old or traditional culture; it is an act of returning the tradition to certain people or groups. In his theory, Hobsbawn explained that:

"Invented tradition' [which] is taken to mean a set of practices, normally governed by overtly or tacitly accepted rules and of a ritual or symbolic nature, which seek to inculcate certain values and norms of behavior by repetition, which automatically implies continuity with the past... [it] is essentially a process of formalization and 
ritualization, characterized by reference to the past, if only by imposing repetition" [15].

The innovation is called cultural tourism. The development of tourism and cultural escape in this context is the material in cultural commodification. Culture, tradition, and tourism are linked when people owning the culture harmonize cultural values with tourism so that traditional innovation and traditions based on the past can be formed.

The scheme of reviving culture in the Malangan mask tradition in the Polowijen area is related to modern elements fully represented in the invented tradition. This invented tradition pattern is not only about the traditional form but also its inversion into a modern form; it collided with the emergence process and a gradual creative process through the festival. In this case, the tradition formed is to carry out the typical Polowijen Malangan Mask purification ritual accompanied by a prayer led by Ki Demang. The ritual of purifying the Malangan Mask is a new formation after Polowijen became a cultural village; the ritual was nonexistent before KBP. In addition, there are stages before the mask is 'purified' in Mbah Reni's burial, such as the mubeng desa (a parade of going around the entire village) and petilasan (visiting sacred sites), which ends with a prayer.

The Covid-19 pandemic has made KBP managers and the community adjust the sesekaran topeng tradition's implementation as one of the tourism attractions. The procession was carried out involving a limited number of participants and live-broadcasted through KBP's YouTube channel. The ritual begins with 'purifying the mask at Mbah Reni's burial; this media conveys the message to tourists. KBP is a tourist destination trying to survive the Covid-19 pandemic. Through tourism networks and literacy in e-tourism, it responds to the situation's challenges and be resilient to the global pandemic. Community involvement in tourism activities can be seen as a strategy of resilience. According to Reivich and Shatte [6], resilience is the ability to cope and adapt when facing changes, including the capacity and ability to respond to situations.

The encouragement of the tourism industry comes from tourists' demand and support from the government. It attempts to replace people's memory with knowledge; trying to dig up other people's memories is a process called creative recall [16]. New settlers recall the indigenous people's memories differently by being activists of KBP.

\section{Conclusion}

The exposure and spread of Covid-19 have caused a global catastrophe. The disaster has brought a high economic impact due to restrictions on access and mobilization arrangements. Tourism is also exposed to Covid-19. It has experienced a significant decrease in tourist visits and affected its income. In the current situation, KBP slowly adapts by packing offerings or tourist attractions virtually. The virtualized attraction is the tradition of sesekaran topeng. Although tourism has experienced fragility in the pandemic, it has slowly become resilient and adapted to the new-normal condition by still presenting visual tourism.

\section{References}

[1] I. D. G. Sugihamretha, "Respon Kebijakan: Mitigasi Dampak Wabah Covid-19 Pada Sektor Pariwisata,” J. Perenc. Pembang. Indones. J. Dev. Plan., vol. 4, no. 2, pp. 191-206, 2020.

[2] C. Hor and N. Thaiprasert, "Analysis of international tourism demand for Cambodia," in Econometrics of risk, Springer, 2015, pp. 415-425. 
[3] C. F. Tang and E. C. Tan, "The determinants of inbound tourism demand in Malaysia: another visit with non-stationary panel data approach," Anatolia, vol. 27, no. 2, pp. 189-200, 2016.

[4] C. F. Tang and E. Lau, "Modelling the demand for inbound medical tourism: The case of M alaysia," Int. J. Tour. Res., vol. 19, no. 5, pp. 584-593, 2017.

[5] B. Gopalakrishnan, R. Peters, and D. Vanzetti, "Covid-19 and Tourism," 2020.

[6] K. Reivich and A. Shatté, The resilience factor: 7 essential skills for overcoming life's inevitable obstacles. Broadway books, 2002.

[7] J. Postill and S. Pink, "Social media ethnography: The digital researcher in a messy web," Media Int. Aust., vol. 145, no. 1, pp. 123-134, 2012.

[8] T. R. Dunn and W. B. Myers, "Contemporary Autoethnography Is Digital Autoethnography: A Proposal for Maintaining Methodological Relevance in Changing Times,” J. Autoethnography, vol. 1, no. 1, pp. 43-59, 2020.

[9] C. M. Hall, Tourism planning: Policies, processes and relationships. Pearson Education, 2008.

[10] D. T. Raharjana, "Membangun pariwisata bersama rakyat: Kajian partisipasi lokal dalam membangun Desa wisata di dieng plateau," J. Kawistara, vol. 2, no. 3, 2012.

[11] J. Briggs and J. Sharp, "Indigenous knowledges and development: a postcolonial caution," Third World Q., vol. 25, no. 4, pp. 661-676, 2004.

[12] A. Stronza, "Anthropology of tourism: Forging new ground for ecotourism and other alternatives," Annu. Rev. Anthropol., vol. 30, no. 1, pp. 261-283, 2001.

[13] A. Bennett and I. Woodward, "Festival spaces, identity, experience and belonging," in The festivalization of culture, Routledge, 2016, pp. 25-40.

[14] INSPIRE Media TV, "Virtual Culture Tourism - Sesekaran Topeng Malang "Anoman Gandrung,", 2020.

[15] E. J. Hobsbawn, "Les enjeux du XXIème siècle,” Complexe, Paris, 2000.

[16] T. R. Landry, "Touring the slave route: inaccurate authenticities in Bénin, West Africa," in $A$ Museum Studies Approach to Heritage, Routledge, 2018, pp. 189-204. 